\title{
Integrated Supply Chain Contract Model With Drop-Shipper Players
}

\author{
Muhammad Faisal Ibrahim \\ Program Studi Teknik Logistik, Universitas Internasional Semen Indonesia \\ Kompleks PT. Semen Indonesia (Persero), Jl. Veteran, Sidokumpul, Gresik, Jawa Timur 61122 \\ Korespondensi penulis, surel: faisalibrahim.ie@gmail.com
}

\begin{abstract}
In this paper, we developed model integrated supply chain model with drop-shipper players. The aim of the study is to integrate players in the supply chain system that one of its players is a drop shipper. This coordination model considers the policy of late payment and prosecution for delivery of goods. Previous, The author has described the supply chain system in detail. The experiments were conducted into different case scenarios, where each scenario would represent the actual system that occurred. Then also conducted sensitivity analysis on some predicted variables significantly influence the total cost of the supply chain. From the results obtained, it can be concluded that coordination with consideration of delay in payment and penalty contract for drop ship has successfully integrated the players in the supply chain system under study. This can be proved by the lower total cost of the supply chain when it is integrated with that consideration.
\end{abstract}

Keywords: Supply chain contract, delay in payment, penalty contract.

\begin{abstract}
Abstrak
Model yang dikembangkan dalam penelitian ini bertujuan untuk mengintegrasikan pemain dalam sistem rantai pasok yang salah satu pemainnya adalah drop-shipper. Model koordinasi ini menggunakan pertimbangan kebijakan delay in payment dan kontrak penalti untuk drop-shipper. Penulis telah menggambarkan sistem rantai pasok secara detail sebelumnya. Percobaan dilakukan kedalam berbegai skenario kasus berbeda, di mana masing-masing skenario kasus tersebut akan merepresentasikan sistem nyata yang terjadi. Kemudian juga dilakukan analisa sensitivitas pada beberapa variabel yang diprediksi berpengaruh secara signifikan terhadap total biaya rantai pasok. Dari hasil yang diperoleh, dapat disimpulkan bahwa koordinasi dengan pertimbangan delay in payment dan kontrak penalti untuk drop-shipper berhasil mengintegrasikan pemain-pemain dalam sistem rantai pasokan yang diteliti. Hal tersebut dapat dibuktikan dengan total biaya rantai pasok yang lebih rendah saat dilakukan integrasi dengan pertimbangan tersebut.
\end{abstract}

Kata kunci: Kontrak rantai pasok, penundaan pembayaran, kontrak penalti.

\section{Pendahuluan}

Manajemen rantai pasok (supply chain management - SCM) menjadi sangat penting bagi suatu perusahaan dalam mencapai target yang diharapkan. SCM memiliki peranan yang tinggi dalam peningkatan daya saing dan keberlanjutan suatu perusahaan. Suatu perusahaan dapat menggunakan strategi yang sudah ada maupun merancang strategi baru untuk meningkatkan performa rantai pasok mereka. Salah satu strategi yang dapat digunakan adalah dengan melakukan kerja sama, koordinasi, merancang kontrak, dan hal sejenis lainnya dengan tujuan meningkatkan daya saing. Menurut Seuring [1], kerja sama merupakan satu-satunya cara bagi suatu perusahaan dalam meningkatkan performa rantai pasok. SCM dapat digunakan dalam mengintegrasikan beberapa perusahaan dengan cara mengoordinasikan aliran bahan, informasi, dan keuangan [2]. Sebagai contoh, Glock [3] melakukan penelitian tentang koordinasi dengan 
Join economic lot sizing diantara pemain dalam rantai pasokan agar tercipta SCM yang berkelanjutan. Dengan fokus kepada SCM yang berkelanjutan, persediaan di seluruh rantai pasokan akan menjadi lebih efisien saat dikelola dengan kerja sama dan koordinasi yang lebih baik. Tujuan utama dari koordinasi antara para pemain dalam rantai pasokan adalah untuk meminimumkan biaya rantai pasokan secara keseluruhan. Akibat dari koordinasi yang berhasil adalah peningkatan penjualan karena peningkatan profitabilitas rantai pasokan [4]. Sulit untuk berbagi informasi lengkap dalam rantai pasokan desentralisasi, karena sebagian besar anggotanya adalah perusahaan independen yang fokus pada usaha memaksimalkan keuntungan mereka sendiri [5]. Skenario sentralisasi dengan pengambilan keputusan secara bersama memungkinkan untuk meningkatkan keuntungan total rantai pasokan [6].

Keringanan penundaan pembayaran tanpa beban bunga selama jangka waktu tertentu lebih populer dengan sebutan delay in payment. Kebijakan tersebut merupakan salah satu cara koordinasi dengan memperbolehkan pelanggan menunda pembayaran kepada vendor selama periode tertentu tanpa beban bunga [7]. Kebijakan tersebut juga akan menarik pembeli (pemain satu level dibawahnya) untuk membeli pada lot yang lebih besar dari jumlah pemesanan ekonomis mereka. Dengan meningkatnya kuantitas order pembeli, maka persediaan akan berpindah kepada pembeli [8]. Menurut Goyal [9] ketika supplier memberi suatu periode penundaan pembayaran, secara tidak langsung supplier memberi pelanggan pinjaman tanpa beban bunga hingga akhir periode tersebut. Sehingga umumnya pelanggan akan menahan hingga akhir waktu yang diberikan. Pada sisi lain, pembeli juga mendapatkan keuntungan dengan menginvestasikan pinjaman mereka pada investasi bebas risiko selama periode yang diizinkan. Jika pembeli membayar diluar waktu yang telah diizinkan maka akan dikenakan bunga.

Penjualan online retail diperkirakan akan terus tumbuh dari $7 \%$ atas penjualan retail secara keseluruhan pada tahun 2011, dan menjadi 9\% pada tahun 2016 [10]. Dalam model drop-shipping internet retailing, supplier akan memegang persediaan dan juga akan melaksanakan layanan distribusi fisik atas nama drop-shipper [11]. Sehingga dropshipper hanya berfokus pada penjualan, sedangkan proses fisik tetap akan ditangani oleh supplier mereka. Saluran drop-shipping menjadi lebih efisien dibandingkan dengan saluran tradisional, karena pada umumnya pada saluran tradisional sering terjadi kurangnya koordinasi [12]. Ketika merancang kontrak untuk mengoordinasikan channel drop-shipper, distributor memiliki kekuatan negosiasi yang lebih dalam pengambilan profit. Sehingga, tidak salah jika suatu distributor juga menjual produknya melalui dropshipper disamping saluran tradisional. Masalah ini adalah salah satu yang akan menjadi sorotan dalam penelitian ini, saat distributor tidak hanya memiliki rekan retailer (traditional channel), tetapi juga drop-shipper (internet channel). Pada penelitian sebelumnya Gan, et al. [13] mengemukakan bahwa, umumnya drop-shipper memiliki informasi permintaan pelanggan yang lebih baik dari pada distributor. Sering kali dropshipper mengirimkan perkiraan permintaan yang jumlahnya lebih dari estimasi mereka dengan tujuan memaksimalkan kepentingan mereka sendiri, sehingga mereka berharap persediaan distributor akan selalu mampu dalam menangani permintaan mereka. Disisi lain karena drop-shipper tidak memiliki persediaan, maka mereka beranggapan permintaan tidak akan selalu terpenuhi karena kekurangan persediaan distributor. Perkiraan permintaan yang lebih dari estimasi penjualan drop-shipper, bisa jadi akan mengakibatkan overstock pada distributor. Hal seperti itu akan merugikan distributor sebagai pengelola inventory. Untuk dapat mengatasi permasalahan tersebut harus dibuat kontrak komitmen penalti. Tentunya kontrak tersebut harus menguntungkan kedua pihak dengan tujuan untuk memberikan kepastian lebih untuk permintaan dan pasokan. 
Beberapa dekade lalu, penelitian yang dilakukan oleh Goyal [9] berhasil mengembangkan model economic order quantity dengan pertimbangan delay in payment. Beberapa penelitian membahas kebijakan delay in payment pada sistem perusahaan yang menggunakan dual sales channel. Dalam perusahaan yang menggunakan sistem dual channel, kebijakan delay in payment dapat menjadi kompensasi atau nilai lebih untuk channel tradisional yang pangsa pasarnya dapat berpindah / ter-kanibalisme oleh direct channel [14]. Beberapa penelitian tentang delay in payment yang berfokus pada fungsi tujuan menentukan lot size optimal telah dibahas oleh Chung, et al. [15], Nurshanti [14], Glock [3], dan Jaber and Osman [7]. Aljazzar, et al. [8] mencoba mengembangkan model delay in payment satu eselon dengan fungsi tujuan panjang waktu. Kemudian, Aljazzar, et al. [4] mencoba mengembangkan model delay in payment tersebut menjadi dua eselon. Marchi, et al. [6] mengembangkan model sharing investasi yang saling menguntungkan antara vendor dan buyer. Penelitian tentang drop-shipper telah dilakukan oleh beberapa peneliti walaupun tidak banyak. Pengembangan model strategis untuk penentuan harga dan ukuran pemesanan pada rantai pasokan dengan drop-shipping, telah dilakukan oleh Chiang and Feng [12]. Pada penelitiannya tersebut dikembangkan model EOQ untuk interaksi diantara manufaktur dan retailer / drop-shipper dengan melakukan joint pricing dan lot sizing decision. Penulis mengemukakan bahwa pada manufaktur yang memiliki channel drop-shipper, kontrol penuh lot-sizing dipegang oleh drop-shipper. Pada penelitian yang dilakukan oleh Gan, et al. [13], dikembangkan model kontrak penalti yang bertujuan agar supplier dapat mendapatkan informasi demand retailer dengan lebih valid dan expected profit supplier akan dapat dimaksimumkan.

Kontribusi dalam penelitian ini akan difokuskan pada integrasi dari rantai pasokan tiga eselon, yaitu supplier, manufacturer, distributor, dan drop-shipper. Pertimbangan yang akan digunakan adalah koordinasi delay in payment pada eselon 1 dan 2, juga kontrak penalti pada eselon 3. Problem dalam penelitian ini akan dimodelkan dan diselesaikan dengan mengasumsikan waktu panjang siklus secara umum. Dengan menggunakan simulasi berbagai macam kasus yang dapat merepresentasikan masalah sistem rantai pasokan yang telah dijelaskan sebelumnya, akan dihitung biaya total rantai pasokan dalam berbagai macam kasus tersebut. Juga akan dibandingkan total biaya rantai pasokan saat ada atau tidaknya penawaran delay in payment dan kontrak penalti. Pada akhirnya penulis akan melakukan analisa sensitivitas pada beberapa variabel yang signifikan terhadap perubahan total biaya rantai pasokan. Sehingga dapat mengidentifikasi skenario terbaik dari setiap pemain dalam rantai pasokan.

\section{Metode Penelitian}

\subsection{Gambaran Umum Masalah}

Suatu perusahaan manufaktur sudah pasti akan selalu berhubungan dengan perusahaan lainnya dalam sistem rantai pasokan. Hal tersebut terjadi dengan tujuan optimalisasi performansi perusahaan. Seluruh perusahaan yang berada dalam satu sistem rantai pasokan akan disebut pemain dalam rantai pasokan tersebut. Pada model yang akan dibangun ini terdiri dari beberapa para pemain dalam rantai pasokan yaitu supplier, manufaktur, distributor, dan drop-shipper. Manufaktur akan memproduksi produk dengan mendapatkan supply bahan baku dari supplier. Kemudian produk jadi manufaktur akan di distribusikan oleh distributor. Distributor memiliki rekan bisnis pada level dibawahnya, yaitu drop-shipper.

Dalam proses transaksinya, manufaktur diberi keringanan penundaan pembayaran selama jangka waktu tertentu oleh supplier. Tidak jauh berbeda, pada manufaktur juga memberikan keringanan penundaan pembayaran selama jangka waktu 
tertentu kepada distributor. Jika manufaktur melakukan pembayaran diluar batas waktu yang diberikan maka akan dikenakan beban bunga kepada supplier. Begitu juga pada distributor yang akan terkena beban bunga kepada manufaktur jika melakukan pembayaran diluar batas waktu yang diberikan. Distributor memutuskan mencoba bekerja sama dengan drop-shipper dengan tujuan agar dapat meningkatkan penjualan. Namun untuk media koordinasi yang saling menguntungkan antara kedua belah pihak maka distributor membuat kontrak penalti yang berbasis kuantitas. Sehingga jika dropshipper tidak dapat menjual sesuai kuantitas yang disepakati maka akan terkena beban penalti kepada distributor. Begitu juga jika distributor tidak dapat menyediakan sesuai kontrak penalti yang telah disetujui, maka distributor akan terkena beban penalti kepada drop-shipper, gambaran sistem secara umum dapat dilihat pada Gambar 1.

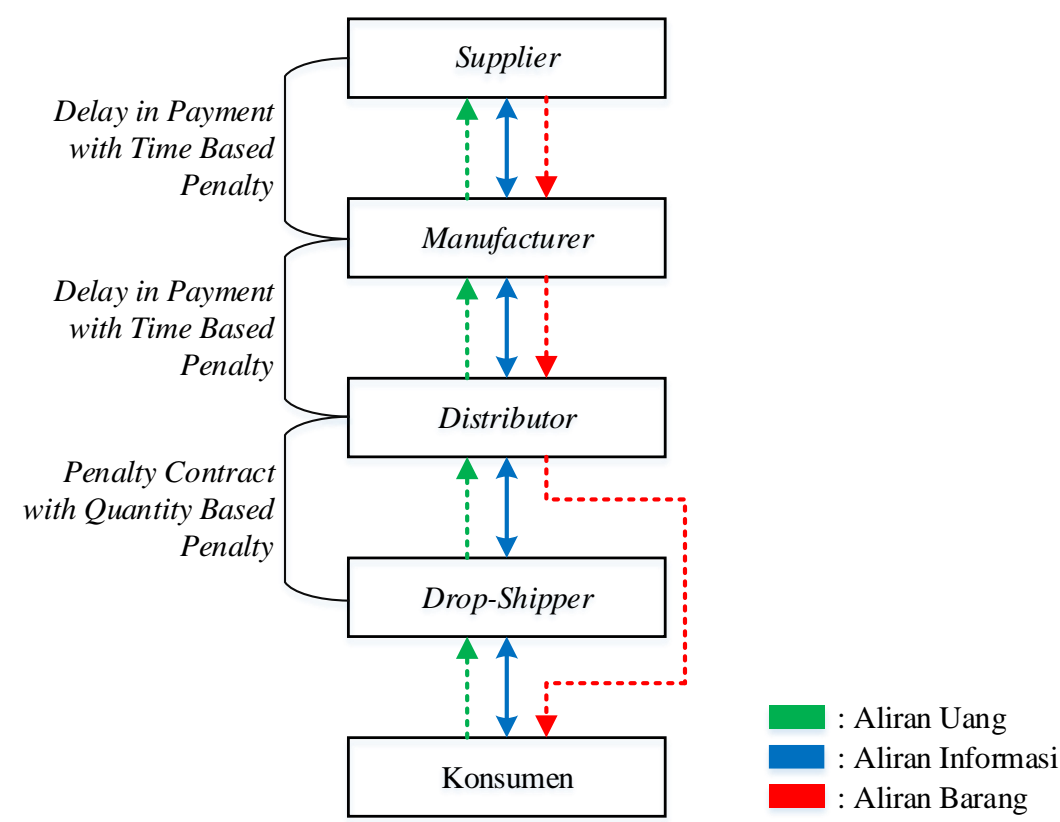

Gambar 1 Gambaran umum model

Tujuan dari pengembangan model ini adalah untuk mengintegrasikan seluruh pemain dalam sistem rantai pasokan tersebut. Koordinasi dilakukan dengan delay in payment pada eselon satu. Sedangkan pada eselon dua koordinasi akan dilakukan dengan kontrak penalti. Sehingga biaya total sistem secara keseluruhan dapat diminimasi, dan terciptanya sistem rantai pasokan yang berkelanjutan. Dapat dilihat pada Gambar 1, aliran informasi akan mengalir dari hilir ke hulu ataupun sebaliknya, sedangkan aliran barang mengalir dari hulu ke hilir. Terdapat perbedaan pada aliran barang yang mengalir dari hulu ke hilir tanpa melewati drop-shipper.

\subsection{Pengembangan model}

Pada penelitian ini penulis berusaha menggambarkan kondisi sistem nyata yang terjadi belakangan ini, di mana perkembangan internet memunculkan pemain baru dalam rantai pasokan. Sehingga hal tersebut akan memaksa desain rantai pasok menjadi berbeda dari pada umumnya. Penulis ingin memodelkan bagaimana integrasi pemainpemain dalam rantai pasokan tiga eselon, yang mana salah satu pemainnya adalah dropshipper. Sehingga ada empat pemain utama, yaitu supplier, manufaktur, distributor, dan drop-shipper, sebelum akhirnya produk jatuh ke tangan konsumen akhir. Pertimbangan 
yang digunakan pada penelitian ini adalah delay in payment dan kontrak penalti untuk drop-shipper. Oleh karena itu penulis berusaha mencari penelitian-penelitian terdahulu yang berkaitan dengan delay in payment dan drop-shipping. Model matematis yang akan dibangun pada penelitian ini berfokus pada rujukan utama, yaitu Aljazzar, et al. [4] ; Jaber, et al. [16]; Khouja and Stylianou [17]; Gan, et al. [13], penulis mengombinasikan beberapa model yang relevan dalam penelitian-penelitian tersebut. Sehingga dapat dikembangkan model yang dapat diaplikasikan pada sistem rantai pasok pada penelitian ini. Pada eselon 1 dan 2 akan dibangun model koordinasi dengan pertimbangan delay in payment dan pada eselon 3 akan dibangun model koordinasi dengan pertimbangan kontrak penalti. Proses validasi dan verifikasi akan dilakukan secara implisit saat penulis melakukan pengembangan model. Validasi dilakukan dengan tujuan membuktikan model yang telah dikembangkan merepresentasikan realitas yang ada. Sementara verifikasi dilakukan untuk menentukan apakah model matematis yang telah dikembangkan merepresentasikan model konseptual yang dijelaskan sebelumnya.

\section{Secara umum ada dua sub kasus pada eselon 1, yaitu :}

1. $0 \leq t_{s}=\tau_{m} \leq \frac{n_{2} Q}{P n_{1}}$ : Terdapat 2 pemain yang terlibat pada eselon 1 , yaitu supplier dan manufaktur. Dalam sub kasus ini supplier memberi delay in payment selama periode waktu $t_{s}$ kepada manufaktur untuk menyelesaikan pembayaran tanpa beban bunga. Manufaktur melakukan pembayaran pada periode waktu $\tau_{m}$, waktu pembayaran tersebut tepat pada akhir periode delay in payment yang diberikan oleh supplier $t_{s}$. Sehingga pada sub kasus ini manufaktur tidak akan memberikan kompensasi kepada supplier karena melakukan pembayaran tidak melebihi batas periode delay in payment yang diberikan supplier.

2. $0 \leq t_{s}<\tau_{m} \leq \frac{n_{2} Q}{P n_{1}}$ : Terdapat 2 pemain yang terlibat pada eselon 1 , yaitu supplier dan manufaktur. Dalam sub kasus ini supplier memberi delay in payment selama periode waktu $t_{s}$ kepada manufaktur untuk menyelesaikan pembayaran tanpa beban bunga. Manufaktur melakukan pembayaran pada periode waktu $\tau_{m}$, waktu pembayaran tersebut terjadi setelah akhir periode delay in payment yang diberikan oleh supplier $t_{s}$ dan sebelum menerima pengiriman selanjutnya. Sehingga pada sub kasus ini manufaktur harus akan memberikan kompensasi kepada supplier karena melakukan pembayaran melebihi batas periode delay in payment yang diberikan supplier.

\section{Terdapat dua sub kasus pada eselon 2, yaitu :}

1. $0 \leq t_{m}=\tau_{d} \leq \frac{Q}{D}$ : Terdapat 2 pemain yang terlibat pada eselon 2 , yaitu manufaktur dan distributor. Dalam sub kasus ini manufaktur memberi delay in payment selama periode waktu $t_{m}$ kepada distributor untuk menyelesaikan pembayaran tanpa beban bunga. Distributor melakukan pembayaran pada periode waktu $\tau_{d}$, waktu pembayaran tersebut tepat pada akhir periode delay in payment yang diberikan oleh manufaktur $t_{m}$. Sehingga pada sub kasus ini distributor tidak akan memberikan kompensasi kepada manufaktur karena melakukan pembayaran tidak melebihi batas periode delay in payment yang diberikan manufaktur.

2. $0 \leq t_{m}<\tau_{d} \leq \frac{Q}{D}$ : Terdapat 2 pemain yang terlibat pada eselon 2 , yaitu manufaktur dan distributor. Dalam sub kasus ini manufaktur memberi delay in payment selama periode waktu $t_{m}$ kepada distributor untuk menyelesaikan pembayaran tanpa beban bunga. Distributor melakukan pembayaran pada periode waktu $\tau_{d}$, waktu pembayaran tersebut terjadi setelah akhir periode delay in payment yang diberikan oleh manufaktur $t_{m}$ dan sebelum menerima pengiriman selanjutnya. Sehingga pada 
sub kasus ini distributor harus akan memberikan kompensasi kepada manufaktur karena melakukan pembayaran melebihi batas periode delay in payment yang diberikan manufaktur.

Terdapat dua sub kasus pada eselon 3, yaitu :

1. $m=Q>Q_{d s}$ : Terdapat 2 pemain yang terlibat pada eselon 3 , yaitu distributor dan drop-shipper. Pada sub kasus ini dalam satu siklus umum $T=\frac{n_{2} Q}{D}$ permintaan distributor sama dengan komitmen kuantitas yang telah disetujui drop-shipper sebelumnya $m$. Namun permintaan drop-shipper $Q_{d s}$ kurang dari komitmen yang telah disetujui sebelumnya. Sehingga pada sub kasus ini drop-shipper harus memberikan kompensasi $w$ kepada distributor karena melakukan pemesanan dengan jumlah dibawah kontrak penalti kuantitas yang telah disetujui sebelumnya.

2. $Q<Q_{d s} \leq m$ : Terdapat 2 pemain yang terlibat pada eselon 3 , yaitu distributor dan drop-shipper. Pada sub kasus ini dalam satu siklus umum $T=\frac{n_{2} Q}{D}$ permintaan distributor kurang dari komitmen kuantitas yang telah disetujui drop-shipper sebelumnya $m$. Ternyata permintaan drop-shipper $Q_{d s}$ sesuai dengan komitmen dan lebih dari permintaan distributor. Sehingga pada sub kasus ini distributor harus memberikan kompensasi $v$ kepada drop-shipper karena tidak dapat memenuhi permintaan drop-shipper yang sesuai dengan jumlah kontrak penalti kuantitas yang telah disetujui sebelumnya.

Formulasi skenario kasus berbeda dibawah setiap kasus utama pada masingmasing eselon dapat dilihat pada Tabel 1.

Tabel 1 Skenario Kasus

\begin{tabular}{|c|c|c|c|}
\hline Eselon 1 & Eselon 2 & Eselon 3 & Nama Kasus \\
\hline \multirow{4}{*}{$0 \leq t_{s}=\tau_{m} \leq \frac{n_{2} Q}{P n_{1}}$} & \multirow{2}{*}{$0 \leq t_{m}=\tau_{d} \leq \frac{Q}{D}$} & $m=Q>Q_{d s}$ & 1.1 .1 \\
\hline & & $Q<Q_{d s} \leq m$ & 1.1 .2 \\
\hline & \multirow{2}{*}{$0 \leq t_{m}<\tau_{d} \leq \frac{Q}{D}$} & $m=Q>Q_{d s}$ & 1.2 .1 \\
\hline & & $Q<Q_{d s} \leq m$ & 1.2 .2 \\
\hline \multirow{4}{*}{$0 \leq t_{s}<\tau_{m} \leq \frac{n_{2} Q}{P n_{1}}$} & \multirow{2}{*}{$0 \leq t_{m}=\tau_{d} \leq \frac{Q}{D}$} & $m=Q>Q_{d s}$ & 2.1 .1 \\
\hline & & $Q<Q_{d s} \leq m$ & 2.1 .2 \\
\hline & \multirow{2}{*}{$0 \leq t_{m}<\tau_{d} \leq \frac{Q}{D}$} & $m=Q>Q_{d s}$ & 2.2 .1 \\
\hline & & $Q<Q_{d s} \leq m$ & 2.2 .2 \\
\hline
\end{tabular}

\section{Hasil dan Pembahasan}

\subsection{Hasil Perhitungan}

Nilai-nilai variabel yang digunakan dalam penelitian ini mengadopsi data dari penelitian terdahulu. Sebagian besar data merujuk pada penelitian yang dilakukan oleh Aljazzar, et al. [4]. Seluruh nilai-nilai variabel yang digunakan dalam penelitian ini dapat dilihat pada Tabel 2. Seluruh notasi yang digunakan dalam formulasi model matematis dapat dilihat pada halaman daftar notasi. Input paremeter yang akan digunakan dalam penelitian ini adalah sebagai berikut : 
Tabel 2 Matriks waktu tempuh

\begin{tabular}{ccccccccccccc}
\hline $\boldsymbol{D}$ & $\boldsymbol{P}$ & $\boldsymbol{a}$ & $\boldsymbol{A}_{\boldsymbol{s}, \boldsymbol{f}}$ & $\boldsymbol{A}_{\boldsymbol{m}, \boldsymbol{w}}$ & $\boldsymbol{A}_{\boldsymbol{m}, \boldsymbol{f}}$ & $\boldsymbol{A}_{\boldsymbol{d}, \boldsymbol{f}}$ & $\boldsymbol{A}_{\boldsymbol{d s}, \boldsymbol{f}}$ & $\boldsymbol{C}_{\boldsymbol{s}, \boldsymbol{f}}$ & $\boldsymbol{C}_{\boldsymbol{m}, \boldsymbol{w}}$ & $\boldsymbol{C}_{\boldsymbol{m}, \boldsymbol{f}}$ & $\boldsymbol{C}_{\boldsymbol{d}, \boldsymbol{f}}$ & $\boldsymbol{C}_{\boldsymbol{d s}, \boldsymbol{f}}$ \\
3069 & 4720 & 1 & 441 & 206 & 175 & 384 & 2.5 & 20 & 30 & 50 & 70 & 80 \\
\hline $\boldsymbol{h}_{\boldsymbol{s}, \boldsymbol{f}}$ & $\boldsymbol{h}_{\boldsymbol{m}, \boldsymbol{w}}$ & $\boldsymbol{h}_{\boldsymbol{m}, \boldsymbol{f}}$ & $\boldsymbol{h}_{\boldsymbol{d}, \boldsymbol{f}}$ & $\boldsymbol{S}_{\boldsymbol{s}, \boldsymbol{f}}$ & $\boldsymbol{S}_{\boldsymbol{m}, \boldsymbol{w}}$ & $\boldsymbol{S}_{\boldsymbol{m}, \boldsymbol{f}}$ & $\boldsymbol{S}_{\boldsymbol{d}, \boldsymbol{f}}$ & $\boldsymbol{n}_{\mathbf{1}}$ & $\boldsymbol{n}_{2}$ & $\boldsymbol{k}_{\boldsymbol{s}}$ & $\boldsymbol{k}_{\boldsymbol{m}}$ & $\boldsymbol{k}_{\boldsymbol{d}}$ \\
3 & 3 & 12 & 13,3 & 3 & 7,5 & 9 & 7,7 & 1 & 2 & $1 \%$ & $8 \%$ & $4 \%$ \\
\hline $\boldsymbol{v}$ & $\boldsymbol{e}$ & $\boldsymbol{w}$ & & & & & & & & & & \\
30 & $10 \%$ & 50 & & & & & & & & & & \\
\hline
\end{tabular}

Adapun langkah-langkah yang dilakukan untuk pencarian solusi optimal dengan bantuan Excel Solver secara singkat adalah sebagai berikut :

Langkah 1. Menetapkan tujuan.

Dalam penelitian ini, tujuan utama dari model yang dibangun adalah untuk meminimasi total biaya rantai pasok secara keseluruhan. Sebagai contoh, pada kasus 1.1.1 total biaya terdiri dari biaya yang dikeluarkan supplier, manufaktur, distributor, dan drop-sihipper pada kejadian di kasus tersebut.

Langkah 2. Menetapkan variabel bebas.

Pada kasus ini beberapa variabel optimal yang akan dicari antara lain adalah $Q, m, t_{s}$, $\tau_{m}, t_{m}$, dan $\tau_{s}$. Solusi akhir dari variabel-variabel tersebut akan menjadi solusi optimal pada suatu kasus. Solusi optimal tersebut dapat dipastikan memiliki biaya rantai pasokan yang paling minimal.

Langkah 3. Menetapkan kendala.

Pada penelitian ini, kendala untuk masing-masing skenario kasus akan berbeda. Perbedaan kendala tersebut menyesuaikan dengan skenario kasus yang ada.

Langkah 4. Mendesain lembar kerja Excel

Yang dimaksud dalam mendesain lenbar kerja ini adalah menetapkan di mana paremeter dasar, variabel keputusan, dan tujuan akan diletakkan. Sebagai contoh, desain lembar kerja skenario kasus 1.1.1 dapat dilihat pada Gambar 2. Pada lembar kerja tersebut terdiri dari berbagai kolom, diantaranya adalah parameter dasar, pembatas, variabel keputusan, dan total biaya.

Langkah 5. Input parameter dasar.

Masing-masing parameter dasar diletakkan pada kolom yang telah disiapkan untuk parameter tersebut. Parameter dasar ini akan digunakan dalam model yang telah dikembangkan sebelumnya.

Langkah 6. Input model komponen biaya.

Model matematis yang akan ditulis harus diterjemahkan terlebih dahulu kedalam formula perhitungan Excel. Formula tersebut diletakkan pada kolom biaya masingmasing pemain kemudian dijumlahkan.

Langkah 7. Solve.

Langkah terakhir yang harus dilakukan adalah menetapkan cell tujuan, variabel peubah, dan kendala pada jendela Solver Parameter. Kemudian dilanjutkan dengan running 
solver. Rancangan solver beserta hasil komputasi untuk penyelesaian masalah skenario kasus 1-1-1 dapat dilihat pada Gambar 2.

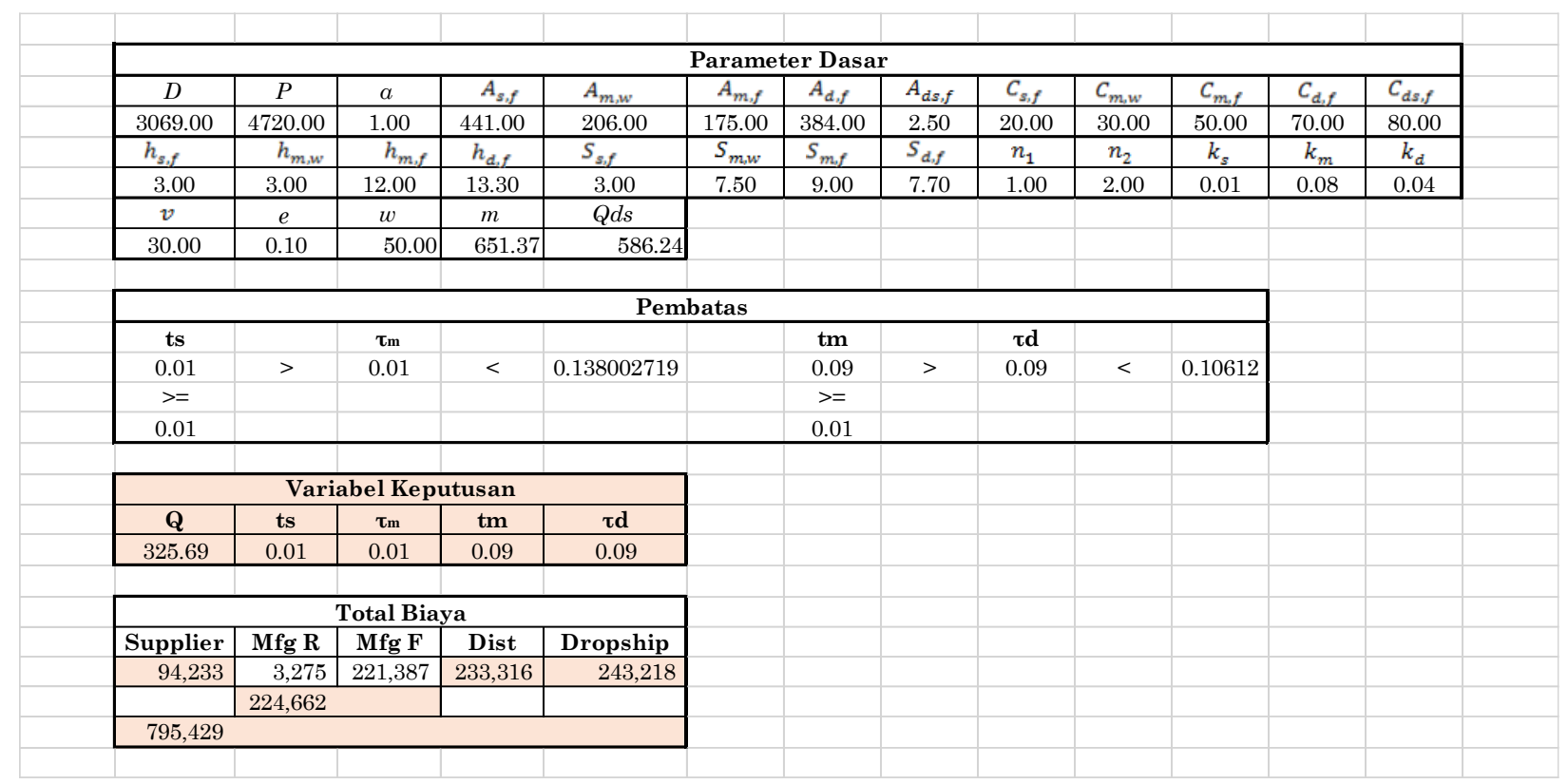

Gambar 2 Work Sheet

Gambar 2 menunjukkan hasil perhitungan yang dilakukan dengan bantuan Solver pada software Excel. Dengan cara yang sama, dilakukan perhitungan untuk seluruh skenario kasus lainnya. Untuk memvalidasi perhitungan tersebut, maka perhitungan numerik juga dilakukan secara manual dengan bantuan software Maple.

Solusi optimal sistem rantai pasokan terjadi pada saat nilai $t_{s}=0.01, t_{m}=0.09$, $\tau_{m}=0.01, \tau_{d}=0.09, Q=326$, dan $m=651$ dengan total biaya yang dikeluarkan sebesar $\$ 795.429$. Solusi optimal yang diperoleh tersebut terjadi pada kasus $1.1 .1\left(0 \leq t_{s}=\tau_{m} \leq\right.$ $\frac{n_{2} Q}{P n_{1}}$ dan $0 \leq t_{m}=\tau_{d} \leq \frac{Q}{D}$ dan $m=Q>Q_{d s}$ ). Dari solusi optimal yang diperoleh terlihat bahwa supplier hanya memberikan manufaktur periode penundaan pembayaran selama periode waktu 0.01 tahun. Periode penundaan pembayaran yang sangat singkat diberikan oleh supplier kepada manufaktur terjadi karena persentase pengembalian investasi supplier yang sangat rendah yaitu sebesar 1\%. Berbeda dengan manufaktur yang memberikan periode penundaan pembayaran selama periode waktu 0.09 tahun kepada distributor. Periode penundaan pembayaran yang relatif panjang tersebut terjadi karena persentase pengembalian investasi manufaktur yang cukup tinggi dibandingkan pemain lainnya, yaitu sebesar $8 \%$. Keputusan optimal yang dipengaruhi oleh panjangnya waktu penundaan pembayaran yang diberikan oleh manufaktur kepada distributor adalah kuantitas pemesanan (Q). Semakin panjang periode waktu penundaan pembayaran yang diberikan oleh manufaktur akan semakin meningkatkan kuantitas pemesanan yang ada. Sebagai contoh, hal tersebut telah dibuktikan dalam percobaan perhitungan pada bab sebelumnya. Pada hasil percobaan tersebut diketahui saat terjadi peningkatan periode waktu penundaan pembayaran yang diberikan oleh manufaktur kepada distributor sebesar $22.22 \%$ menyebabkan peningkatan kuantitas pemesanan sebesar $7.06 \%$. 
Tabel 3 Hasil Perhitungan

\begin{tabular}{cccccccccc}
\hline Skenario & 0.0 .0 & $1.1 .1 *$ & 1.1 .2 & 1.2 .1 & 1.2 .2 & 2.1 .1 & 2.1 .2 & 2.2 .1 & 2.2 .2 \\
\hline $\mathrm{Q}$ & 296 & 326 & 326 & 311 & 311 & 326 & 326 & 311 & 311 \\
$t_{s}$ & 0.00 & 0.01 & 0.01 & 0.01 & 0.01 & 0.01 & 0.01 & 0.01 & 0.01 \\
$\tau_{m}$ & 0.00 & 0.01 & 0.01 & 0.01 & 0.01 & 0.02 & 0.02 & 0.02 & 0.02 \\
$t_{m}$ & 0.00 & 0.09 & 0.09 & 0.06 & 0.06 & 0.09 & 0.09 & 0.06 & 0.06 \\
$\tau_{d}$ & 0.00 & 0.09 & 0.09 & 0.07 & 0.07 & 0.09 & 0.09 & 0.07 & 0.07 \\
$\mathrm{~m}$ & 592 & 651 & 782 & 621 & 745 & 651 & 782 & 621 & 745 \\
$\mathrm{SC}$ & 94,355 & 94,233 & 94,233 & 94,334 & 94,334 & 2,276 & 2,276 & 2,378 & 2,378 \\
$\mathrm{MC}$ & 221,935 & 224,662 & 224,662 & 14,804 & 14,804 & 316,880 & 316,880 & 107,021 & 107,021 \\
$\mathrm{DC}$ & 237,264 & 233,316 & 225,337 & 448,681 & 440,702 & 233,316 & 225,337 & 448,681 & 440,702 \\
$\mathrm{DsC}$ & 243,218 & 243,218 & 266,082 & 243,218 & 266,082 & 243,218 & 266,082 & 243,218 & 266,082 \\
$\mathrm{TSC}$ & 796,773 & 795,429 & 810,314 & 801,038 & 815,922 & 795,691 & 810,575 & 801,299 & 816,183 \\
\hline
\end{tabular}

Dari hasil perhitungan yang dapat dilihat pada Tabel 3, periode waktu penundaan pembayaran dikatakan dapat menjadi media dalam koordinasi antar pemain. Dengan penundaan pembayaran yang lebih panjang akan meningkatkan kuantitas pemesanan, sehingga persediaan akan berpindah dari hulu ke hilir. Sebagai contoh, persediaan yang berpindah dari gudang produk jadi manufaktur ke distributor. Manufaktur dapat diuntungkan dengan jumlah pembelian yang lebih banyak sedangkan distributor juga dapat diuntungkan dengan bunga investasi bebas risiko yang lebih banyak juga. Pada kontrak kuantitas pemesanan dengan drop-shipper $(m)$, distributor memiliki peran lebih dalam penentuan kuantitas pemesanan tersebut. Sehingga kuantitas pemesanan tersebut menyesuaikan dengan kuantitas pemesanan distributor kepada manufaktur. Drop-shipper bisa jadi harus mengeluarkan biaya tambahan karena pemesanan yang berada dibawah kontrak kuantitas. Namun dengan begitu drop-shipper juga akan mendapatkan kompensasi apabila distributor tidak bisa memenuhi permintaan dropshipper yang masih pada batasan kontrak yang ada. Sehingga kontrak penalti kuantitas ini juga dapat dikatakan dapat menjadi media koordinasi antar pemain dalam rantai pasokan. Setelah melakukan pengamatan pada hasil solusi optimal yang telah didapatkan. Dapat disimpulkan bahwa pemberian periode waktu penundaan pembayaran dan perancangan kontrak penalti dapat menjadi media koordinasi yang baik diantara para pemain didalam sistem rantai pasokan yang sedang diteliti.

\subsection{Analisa Sensitivitas}

Analisa sensitivitas dilakukan dengan cara mencoba variasi parameter yang diperkirakan dapat memiliki pengaruh besar pada total biaya sistem sebagai fungsi tujuan. Melalui analisa sensitivitas dapat dilihat seberapa baik model yang dikembangkan berada dalam kondisi yang efektif dan optimal.

Dapat dilihat pada Gambar 3, semakin tinggi persentase pengembalian investasi distributor maka akan membuat penurunan total biaya rantai pasokan. Setelah melakukan analisa, dapat disimpulkan penurunan total biaya rantai pasokan tersebut terjadi akibat beberapa kejadian yang berhubungan langsung dengan peningkatan persentase pengembalian investasi distributor. Saat persentase pengembalian investasi distributor meningkat maka akan membuat kuantitas pemesanan yang semakin tinggi juga. Saat terjadi peningkatan persentase pengembalian investasi distributor sebesar 
50\% dari 0.04 menjadi 0.06. Akan meningkatkan kuantitas pemesanan sebesar $7.06 \%$ dari 326 unit menjadi 349 unit. Peningkatan kuantitas pemesanan tersebut secara tidak langsung akan meningkatkan periode waktu penundaan pembayaran yang diberikan oleh manufaktur kepada distributor. Saat kuantitas pemesanan meningkat sebesar $7.06 \%$ dari 326 unit menjadi 349 unit. Maka akan menyebabkan peningkatan periode waktu yang diberikan oleh manufaktur kepada distributor sebesar $22 \%$ dari 0.09 menjadi 0.11 .

\section{Pengujian Terhadap Persentase Pengembalian Investasi Distributor $\left(k_{d}\right)$}

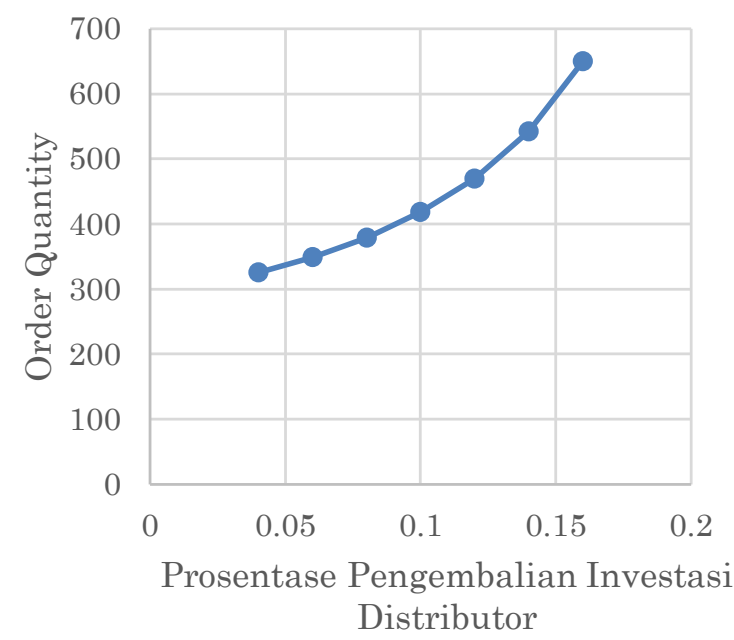

(a)

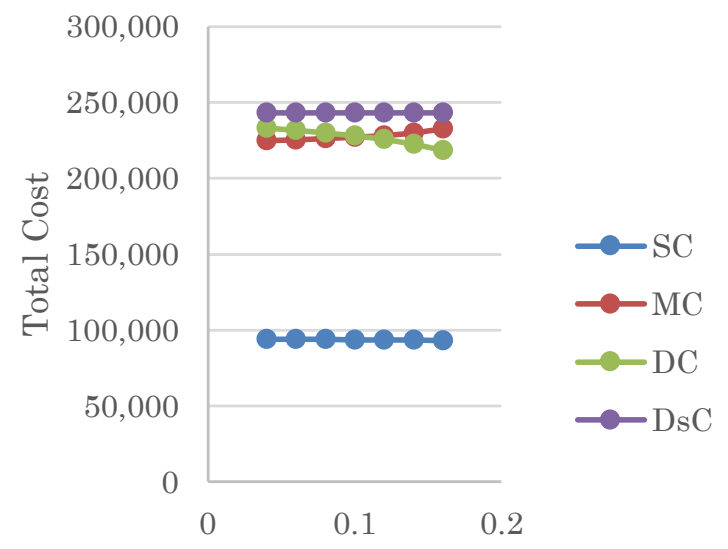

Prosentase Pengembalian Investasi Distributor

(c)

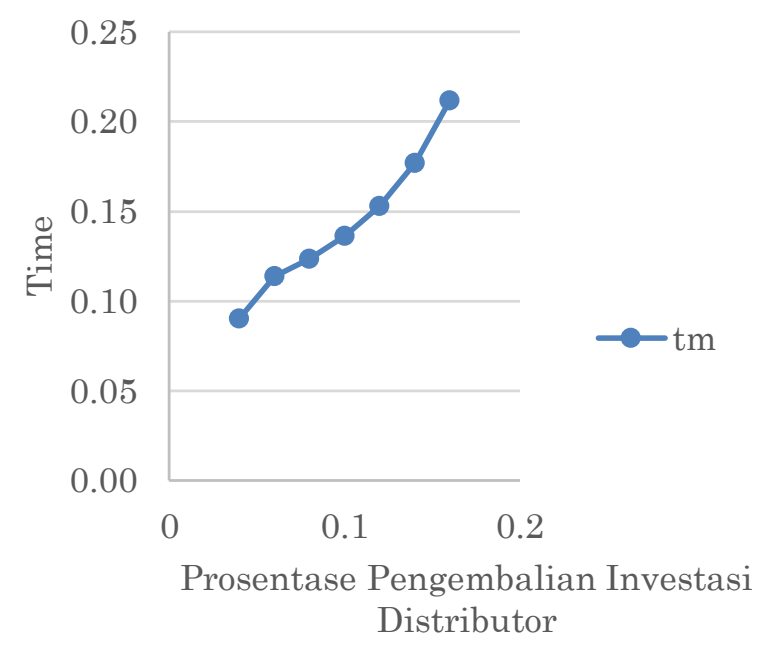

(b)

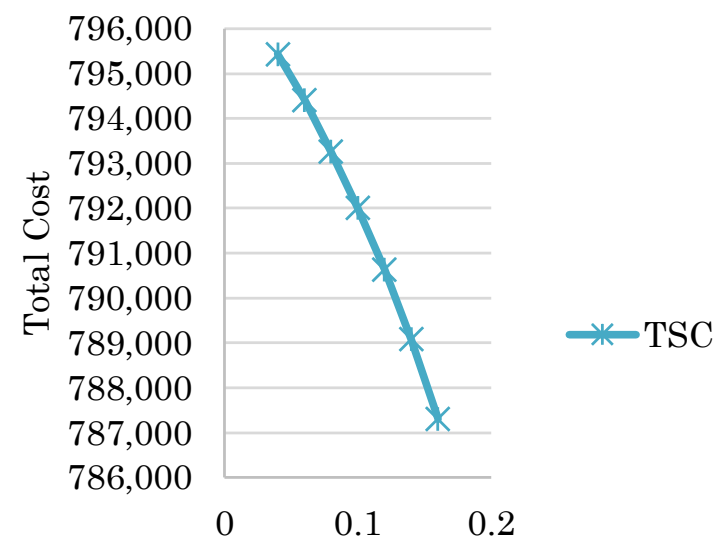

Prosentase Pengembalian Investasi Distributor

(d)

Gambar 3 (a) Pengaruh Prosentase Pengembalian Investasi Distributor Terhadap Kuantitas Pemesanan, (b) Pengaruh Prosentase Pengembalian Investasi Distributor Terhadap Permissible Delay in Payment, (c) Pengaruh Prosentase Pengembalian

Investasi Distributor Terhadap Biaya Setiap Pemain, (d) Pengaruh Prosentase Pengembalian Investasi Distributor Terhadap Total Biaya Sistem Rantai Pasokan

Jika dilihat dari perspektif manufaktur sebagai pemberi periode penundaan pembayaran, semakin tinggi periode penundaan pembayaran yang diberikan kepada 
distributor akan memicu distributor untuk membeli dalam jumlah yang lebih banyak. Hal tersebut mendukung pendapat Aljazzar, et al. [8] yang mengatakan bahwa kebijakan periode penundaan pembayaran untuk pembeli akan menarik pembeli tersebut untuk melakukan pembelian pada lot yang lebih besar. Jika dilihat dari perspektif distributor jika manufaktur memberikan periode penundaan pembayaran yang lebih lama memang akan meningkatkan kuantitas pemesanan distributor, namun hal tersebut juga akan dipengaruhi oleh persentase pengembalian investasi distributor. Semakin tinggi persentase pengembalian investasi distributor akan semakin menguntungkan jika distributor melakukan order dalam jumlah yang lebih besar. Hal tersebut didukung oleh pendapat Goyal [9] yang mengatakan bahwa pembeli akan mendapatkan keuntungan dengan melakukan investasi bebas risiko selama periode penundaan pembayaran yang diberikan penjual. Sehingga beberapa hal tersebut dapat meningkatkan keuntungan masing-masing pemain dalam rantai pasokan, juga keuntungan terintegrasi. Saat tidak adanya periode waktu penundaan pembayaran dan kontrak penalti, justru total biaya yang dikeluarkan lebih tinggi daripada kondisi optimal yang terjadi.

\section{Pengujian Terhadap Permintaan Drop-Shipper $\left(Q_{d s}\right)$}

Informasi permintaan pertama yang diberikan drop-shipper menjadi acuan bagi semua pemain dalam rantai pasokan, sehingga menghasilkan besarnya kuantitas pembelian minimum yang menjadi acuan dalam kontrak. Dengan begitu, drop-shipper akan menanggung beban penalti saat melakukan pembelian dibawah kuantitas pada kontrak dalam satu periode waktu yang disepakati. Hasil percobaan pada Gambar 4 menyimpulkan bahwa distributor tidak merubah kuantitas minimum dalam kontrak walaupun drop-shipper melakukan pemesanan jauh lebih sedikit dari kesepakatan. Terlihat saat permintaan drop-shipper menurun dari semula 586 menjadi 521, distributor tidak merubah kontrak yang telah disetujui yaitu sebesar 651 . Hal tersebut mendukung pendapat Gan, et al. [13] yang mengatakan bahwa supplier (pada kasus ini adalah distributor) memiliki kekuatan negosiasi yang lebih dalam pengambilan profit dalam merancang kontrak untuk drop-shipper. Untuk menggambarkan pengaruh penurunan permintaan drop-shipper terhadap kontrak penalti dengan distributor dapat dilihat pada Gambar 3, saat distributor tidak dapat memenuhi permintaan drop-shipper sesuai kontrak yang disetujui. Permintaan drop-shipper yang tidak sesuai dengan kontrak akan meningkatkan total biaya sistem rantai pasokan secara keseluruhan. Walaupun total biaya yang dikeluarkan drop-shipper menurun, hal tersebut dikarenakan harga produk yang lebih mahal dibandingkan biaya penalti yang harus dibayarkan oleh drop-shipper kepada distributor. Sehingga, total biaya yang terjadi pada drop-shipper terlihat berkurang walaupun order yang terjadi lebih kecil daripada kontrak yang telah disetujui. Begitu juga pada distributor, walaupun distributor tidak merubah kuantitas minimum dalam kontrak penalti dan akan mendapatkan kompensasi dari drop-shipper namun total biaya yang dikeluarkan distributor terlihat meningkat. Hal tersebut juga dikarenakan beban penalti yang diberikan oleh drop-shipper lebih rendah dari pada biaya pembelian suatu produk distributor kepada manufaktur. Namun jika dilihat pada total biaya sistem secara keseluruhan akan meningkat karena ada pemain yang harus membayar beban penalti, yaitu drop-shipper. Sehingga, jika diakumulasikan akan menghasilkan biaya yang lebih tinggi. 


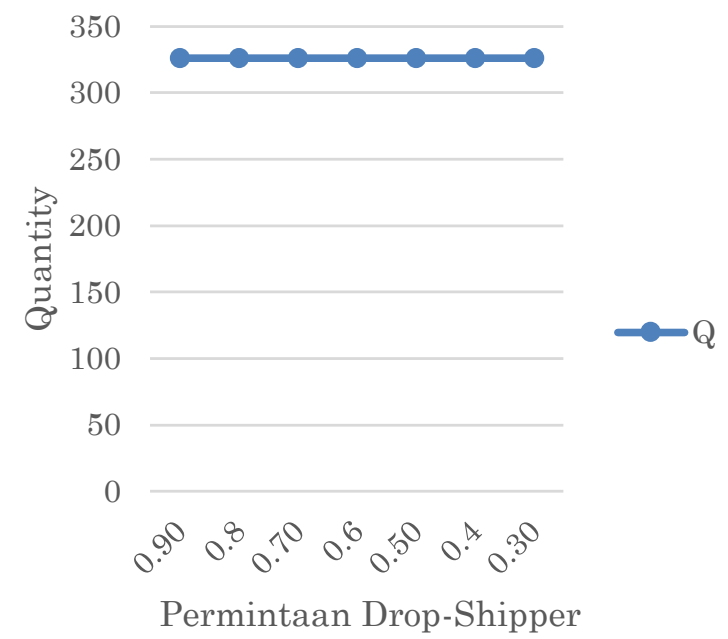

(a)

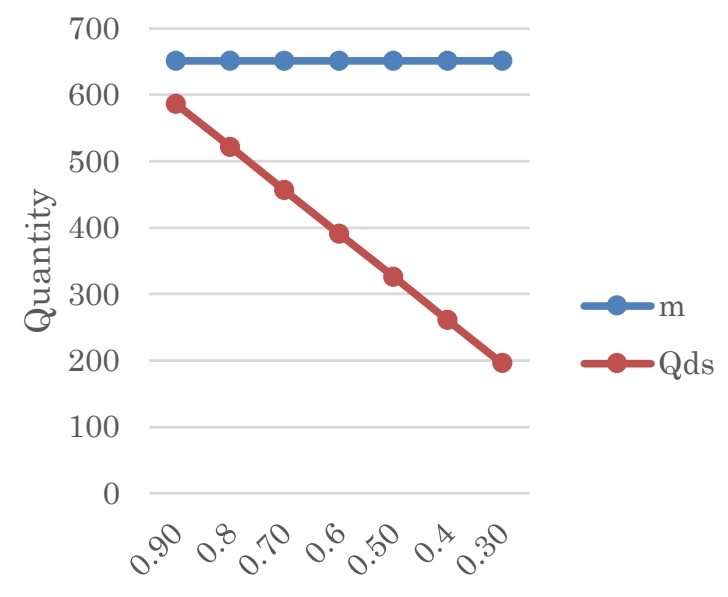

Permintaan Drop-Shiper

(b)

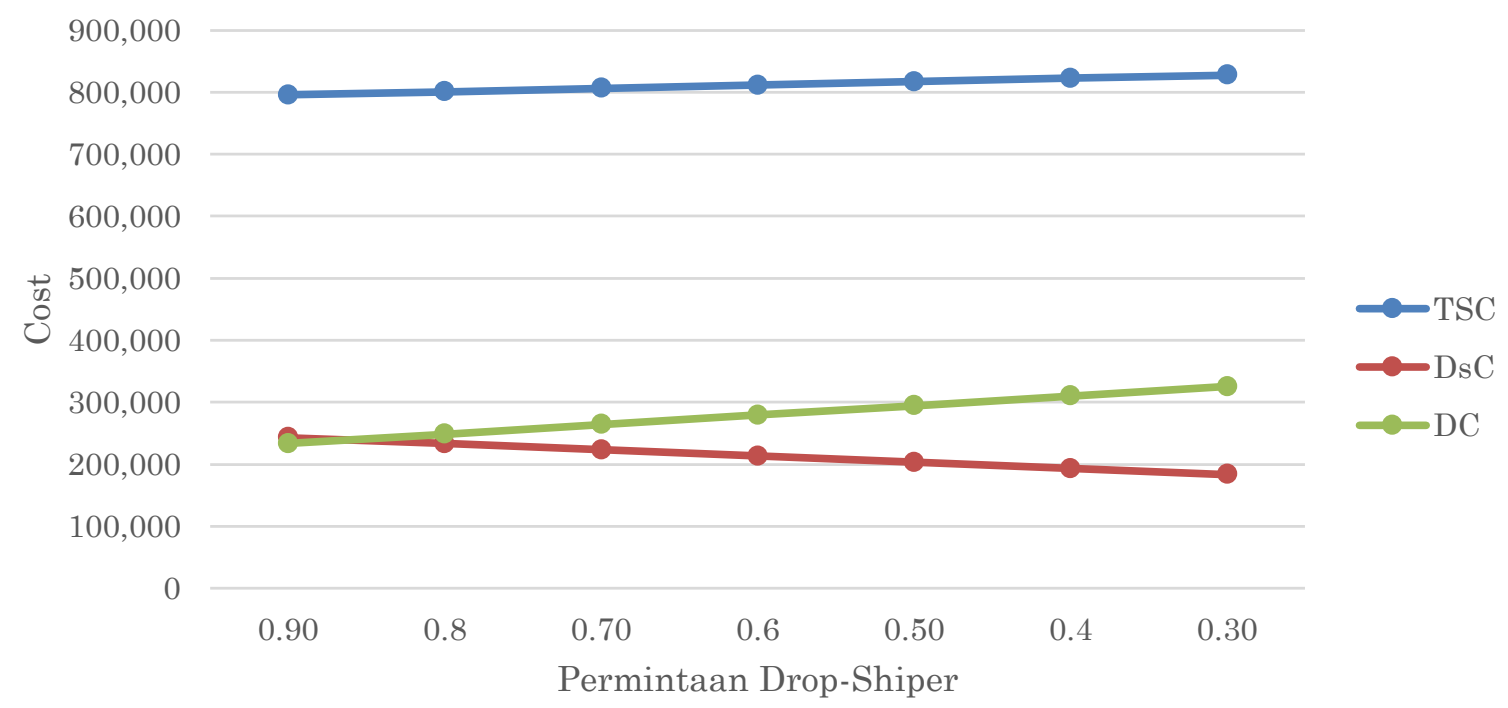

(c)

Gambar 4 (a) Pengaruh Permintaan Drop-Shipper Terhadap Kuantitas Pemesanan, (b) Perbandingan Permintaan Drop-Shipper dan Kontrak Kuantitas Pembelian Minimum, (c) Pengaruh Permintaan Drop-Shipper \& Kontrak Kuantitas Pembelian Minimum Terhadap Total Biaya Sistem Rantai Pasokan

\section{Simpulan}

Koordinasi antar pemain dalam rantai pasokan dengan pertimbangan periode waktu penundaan pembayaran berhasil mengintegrasikan rantai pasokan dengan cukup baik. Hal tersebut dapat terlihat dari total biaya sistem rantai pasokan secara keseluruhan yang lebih rendah jika mempertimbangkan periode waktu penundaan pembayaran daripada tidak mempertimbangkan periode waktu penundaan pembayaran. Dengan diberikannya periode waktu penundaan pembayaran oleh supplier dan manufaktur, maka pemain satu level dibawahnya akan memiliki keuntungan lebih dengan menginvestasikan pendapatan mereka sampai dengan pembayaran dilakukan. Perhitungan numerik yang telah dilakukan menghasilkan kondisi optimal dengan total 
biaya paling minimum. Menurut analisa yang telah dilakukan, panjang atau singkatnya periode waktu pembayaran oleh pembeli dipengaruhi secara signifikan oleh financial holding cost pemain-pemain yang terlibat. Jika pembeli memiliki financial holding cost yang lebih tinggi maka pembeli akan berusaha menunda pembayaran selama mungkin. Dengan adanya koordinasi antara para pemain dalam sistem rantai pasokan terintegrasi yang diteliti. Dapat diambil kesimpulan sangat memungkinkan penjual memberi periode penundaan pembayaran yang lebih panjang jika pembeli memiliki financial holding cost yang tinggi. Namun saat financial holding cost manufaktur meningkat maka supplier akan meningkatkan periode waktu penundaan pembayaran. Hal tersebut dilakukan oleh supplier untuk mempertahankan kuantitas pemesanan yang tinggi dan menjaga total biaya sistem rantai pasokan tetap minimal sesuai dengan tujuan utama integrasi rantai pasokan. Kuantitas pemesanan distributor berpengaruh terhadap kuantitas pemesanan maupun produksi pemain pada level diatasnya. Kuantitas pemesanan optimal tersebut dipengaruhi secara siginifikan oleh periode waktu penundaan pembayaran yang diberikan oleh penjual. Semakin panjang periode waktu penundaan pembayaran yang diberikan oleh penjual akan memaksa pembeli untuk melakukan pemesanan diatas kuantitas optimal pembeli tersebut. Menurut analisa yang telah dilakukan sebelumnya, menyimpulkan bahwa distributor akan bertahan pada kuantitas sesuai kontrak walaupun permintaan drop-shipper terus menurun. Hal tersebut harus dilakukan oleh distributor untuk mempertahankan keuntungan mereka. Di mana drop-shipper harus menanggung biaya yang semakin meningkat karena persediaan yang berlebih. Model yang telah dikembangkan dalam penelitian ini masih memungkinkan untuk dikembangkan kembali dikemudian hari. Adapun saran yang dapat penulis berikan untuk penelitian selanjutnya adalah dalam pengaplikasian periode waktu penundaan pembayaraan perlu dipertimbangkan kompensasi apabila pembeli melakukan pembayaran lebih cepat daripada akhir periode waktu penundaan pembayaran yang diberikan. Juga dalam sistem nyata tidak jarang penjual akan memberikan diskon kepada pembeli.

\section{Daftar Notasi}

$i \quad$ : Pemain rantai pasok (s : supplier, $\mathrm{m}:$ manufacturer, $\mathrm{d}:$ distributor, dan ds : dropshipper).

$j \quad$ : Jenis tingkat persediaan barang ( $\mathrm{w}$ : raw material, $\mathrm{f}$ : finished goods).

$A_{i, j} \quad$ : Biaya setup / pemesanan yang dikeluarkan pemain ke-i terhadap barang ke-j.

$C_{i, j}$ : Biaya produksi / pembelian per item yang dikeluarkan pemain ke-i terhadap barang ke-j.

$h_{i, j} \quad$ : Financial holding cost per item yang dikeluarkan pemain ke-i terhadap barang kej.

$S_{i, j} \quad$ : Physical (storage) holding cost per item yang dikeluarkan pemain ke-i terhadap barang ke-j.

$Q \quad$ : Kuantitas pemesanan distributor.

$Q_{d s}:$ Kuantitas pemesanan drop-shipper.

$n_{1}$ : Jumlah pengiriman oleh supplier kepada manufaktur per siklus bahan baku manufaktur.

$n_{2} \quad$ : Jumlah pengiriman oleh manufaktur kepada distributor per siklus distributor.

$\alpha \quad$ : Jumlah bahan baku yang dibutuhkan untuk memproduksi satu produk jadi.

$t_{i} \quad$ : Periode waktu delay in payments yang ditawarkan oleh pemain ke-i.

$\tau_{i} \quad$ : Waktu pembayaran yang dilakukan oleh pemain ke-i.

$k_{i} \quad$ : Pengembalian investasi untuk pemain ke-i. 
$P \quad$ : Tingkat produksi tahunan manufaktur.

$D \quad$ : Permintaan tahunan distributor $D<P$.

$T \quad$ : Panjang siklus umum $=\frac{n_{2} Q}{D}$.

$T_{S} \quad$ : Panjang siklus supplier $=\frac{n_{2} Q}{P}$.

$T_{w} \quad$ : Panjang siklus bahan baku manufaktur $=\frac{n_{2} Q}{n_{1} P}$.

$T_{m} \quad$ : Panjang siklus produk jadi manufaktur $=\frac{n_{2} Q}{D}$.

$T_{d} \quad$ : Panjang siklus distributor $=\frac{Q}{D}$.

$m \quad$ : Komitmen pembelian minimum drop-shipper.

$v \quad:$ Shortage penalty.

$w \quad$ : Order quantity penalty.

$S C$ : Total biaya tahunan supplier.

$M C$ : Total biaya tahunan.manufaktur.

$D C$ : Total biaya tahunan.distributor.

$D s C$ : Total biaya tahunan.drop-shipper.

TSC : Total biaya tahunan sistem rantai pasokan.

\section{Referensi}

[1] S. Seuring, "Integrated chain management and supply chain management comparative analysis and illustrative cases," Journal of Cleaner Production, vol. 12, pp. 1059-1071, 10// 2004.

[2] H. Stadtler, "Supply chain management and advanced planning--basics, overview and challenges," European Journal of Operational Research, vol. 163, pp. 575-588, 6/16/ 2005.

[3] C. H. Glock, "The joint economic lot size problem: A review," International Journal of Production Economics, vol. 135, pp. 671-686, 2// 2012.

[4] S. M. Aljazzar, M. Y. Jaber, and L. Moussawi-Haidar, "Coordination of a three-level supply chain (supplier-manufacturer-retailer) with permissible delay in payments," Applied Mathematical Modelling, vol. 40, pp. 9594-9614, 11// 2016.

[5] G. Iyer, C. Narasimhan, and R. Niraj, "Information and Inventory in Distribution Channels," Management Science, vol. 53, pp. 1551-1561, 2007.

[6] B. Marchi, J. M. Ries, S. Zanoni, and C. H. Glock, "A joint economic lot size model with financial collaboration and uncertain investment opportunity," International Journal of Production Economics, vol. 176, pp. 170-182, 6// 2016.

[7] M. Y. Jaber and I. H. Osman, "Coordinating a two-level supply chain with delay in payments and profit sharing," Computers \& Industrial Engineering, vol. 50, pp. 385-400, 8// 2006.

[8] S. M. Aljazzar, M. Y. Jaber, and S. K. Goyal, "Coordination of a two-level supply chain (manufacturer-retailer) with permissible delay in payments," International Journal of Systems Science: Operations \& Logistics, vol. 3, pp. 176-188, 2016/07/02 2015.

[9] S. K. Goyal, "Economic Order Quantity under Conditions of Permissible Delay in Payments," The Journal of the Operational Research Society, vol. 36, pp. 335-338, 1985.

[10] D. Z. Yu, T. Cheong, and D. Sun, "Impact of supply chain power and drop-shipping on a manufacturer's optimal distribution channel strategy," European Journal of Operational Research, vol. 259, pp. 554-563, 6/1/ 2017. 
[11] E. Rabinovich, M. Rungtusanatham, and T. M. Laseter, "Physical distribution service performance and Internet retailer margins: The drop-shipping context," Journal of Operations Management, vol. 26, pp. 767-780, 11// 2008.

[12] W. K. Chiang and Y. Feng, "Retailer or e-tailer? Strategic pricing and economic-lotsize decisions in a competitive supply chain with drop-shipping," Journal of the Operational Research Society, vol. 61, pp. 1645-1653, 2010// 2010.

[13] X. Gan, S. P. Sethi, and J. Zhou, "Commitment-penalty contracts in drop-shipping supply chains with asymmetric demand information," European Journal of Operational Research, vol. 204, pp. 449-462, 8/1/ 2010.

[14] I. Nurshanti, "Kebijakan Persediaan Terintegrasi Pada Sistem Dual Sales Channel Mempertimbangkan Penundaan Pembayaran," Master, Industrial Engineering, Sepuluh Nopember Institute of Technology, Surabaya, 2011.

[15] K.-J. Chung, S. K. Goyal, and Y.-F. Huang, "The optimal inventory policies under permissible delay in payments depending on the ordering quantity," International Journal of Production Economics, vol. 95, pp. 203-213, 2/18/ 2005.

[16] M. Y. Jaber, M. Bonney, and A. L. Guiffrida, "Coordinating a three-level supply chain with learning-based continuous improvement," International Journal of Production Economics, vol. 127, pp. 27-38, 9// 2010.

[17] M. Khouja and A. C. Stylianou, "A inventory model with a drop-shipping option for e-business," Omega, vol. 37, pp. 896-908, 8// 2009. 